\title{
Size Effects in Ion-Neutral Complex-Mediated Alkane Eliminations from Ionized Aliphatic Ethers
}

\author{
David J. McAdoo and Charles E. Hudson \\ Marine Biomedical Institute, University of Texas Medical Branch, Galveston, Texas ${ }_{r}$ USA
}

John C. Traeger

Chemistry Department, LaTrobe University, Bundoora, Victoria, Australia

Andrew Grose and Lawrence L. Griffin

Department of Marine Sciences, Texas A\&M University at Galveston, Galveston, Texas, USA

\begin{abstract}
The effects of the size of the ionic and neutral partners on ion-neutral complex-mediated alkane eliminations from ionized aliphatic ethers were determined by obtaining metastable decomposition spectra and photoionization ionization efficiency curves. Increasing the size of the ionic partner decreases the competitiveness of alkane elimination with alkyl loss. This is attributed to decreasing attraction between the partners with increasing distance between the neutral partner and the center of charge in the associated ion. Increasing the size of the neutral partner lowers the threshold for alkane elimination relative to that for simple dissociation when the first threshold is above $\Delta \mathrm{H}_{\mathrm{f}}$ (products). This is attributed to increasing attraction between the partners with increasing polarizability of the radical in the complex. Adding a $\mathrm{CH}_{2}$ to the radical in a complex seems to increase the attraction between the partners by about $24 \mathrm{~kJ} \mathrm{~mol}^{-1}$. (J Am Soc Mass Spectrom 1991, 2, 261-269)
\end{abstract}

$\mathrm{A}$ lkane eliminations from ionized ketones in the gas phase seem to become less important with increasing size of the ionic product and more important with increasing size of the neutral fragment [1]. These eliminations involve hydrogen transfers in intermediate ion-neutral complexes $[1,2]$, reactions which depend strongly on the energy content of the fragmenting ion $[1,3]$. Size effects on this dependence are of interest because they illuminate dynamics of ion-molecule reactions at very low energies.

The partners in intermediate complexes are held in association by ion-dipole and ion-induced dipole attractions. When the neutral partner is nonpolar and the partners are far enough apart that valence forces are not important, the binding energy between the partners is approximated by the formula

$$
E=\alpha q^{2} / 2 r^{4}
$$

where $\alpha$ is the polarizability of the neutral, $q$ is the charge on the ion, and $r$ is the distance between the center of charge and the neutral. Increasing the size of

Address reprint requests to David J. McAdoo, Marine Biomedical Institute, University of Texas Medical Branch, 200 University Boulevard, Galveston, TX 77550 . the ion in the complex should increase $r_{r}$ and therefore decrease the attraction between the partners. This would in turn diminish the competitiveness of internal ion-molecule reactions with associated simple dissociations. On the other hand, the polarizability of alkyl radicals increases with increasing radical size, and therefore so should forces of attraction between them and nearby ions.

The effects of the size of the two types of partners (charged and neutral) were not well separated in our studies of ionized ketones [1]. Therefore, we here investigate size effects more systematically by varying the sizes of the partners in intermediate complexes in decompositions of ionized ethers (Scheme I). Ion-neutral complexes are depicted by placing the partners within brackets.

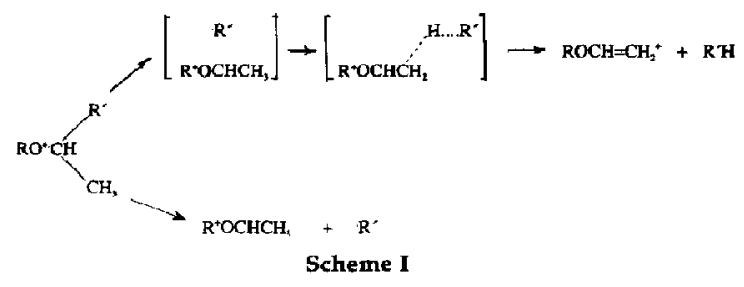




\section{Results and Discussion}

Size effects, potential energy surfaces, and photoionization ionization efficiency curves. One determinant of the importance of alkane elimination relative to alkyl loss is the difference between the thresholds for the two processes. We obtained these differences by determining photoionization appearance energies. The difference $\mathrm{AE}\left(-\mathrm{K}^{\prime}\right)-\mathrm{AE}\left(-\mathrm{R}^{\prime} \mathrm{H}\right)$ is hereafter referred to as $\triangle A E$. A substantial fraction of a complex-mediated alkane elimination often occurs below the threshold for alkyl loss $[1,2 c, 3]$, so increasing $\triangle \mathrm{AE}$ should enhance alkane loss. Size effects will affect the contours of the potential surface in the regions on which $R^{\prime} H$ eliminations occur, and hence $\triangle \mathrm{AE}$.

To understand what determines $\triangle \mathrm{AE}$, it is useful to assume that there are two local energy maxima in the pathway to alkane elimination, one at the transition state for reorientation of the partners to the $\mathrm{H}$-transfer configuration, and one during hydrogen transfer. However, the first transition state may be more an entropic minimum than an energy maximum [4]. A previous discussion of isotope effects suggests that either transition state may be rate determining [2c]. Barriers to $\mathrm{H}$-transfer may place the onset energy for $\mathrm{R} / \mathrm{H}$ elimination above the energy required to form the complex $\left[R^{+}{ }^{\circ C H C H} H_{3} R^{\prime}\right]$ and above $\Delta H_{f}(R O C H$ $\left.=\mathrm{CH}_{2}^{+}\right)+\Delta \mathrm{H}_{\mathrm{f}}\left(\mathrm{R}^{\prime} \mathrm{H}\right)$. The onset for $\mathrm{R}^{\prime} \mathrm{H}$ elimination would then be the energy at which tunneling through the barrier to $\mathrm{H}$-transfer becomes appreciable (Figure 1 , top traces) [5]. [ $\left.\mathrm{R}^{+} \mathrm{OCHCH}_{3} \mathrm{R}^{\prime}\right]$ and $\left[\mathrm{R}^{+} \mathrm{OCH}=\right.$ $\left.\mathrm{CH}_{2}^{+} \mathrm{R}^{\prime} \mathrm{H}\right]$ may both be accessible below $\Delta \mathrm{H}_{\mathrm{f}}$ of the products of alkane elimination (Figure 1 , middle traces). $\triangle \mathrm{AE}$ will then be equal to the difference between the heats of formation of the products of the two decompositions. Finally, the threshold for forming $\left[\mathbf{R}^{+} \mathrm{OCHCH}_{3} \mathbf{R}^{\prime}\right]$ can be above $\Delta \mathrm{H}_{\mathrm{f}}\left(-\mathrm{R}^{\prime} \mathrm{H}\right.$ products) (Figure 1, bottom traces). When this occurs, $\triangle \mathrm{AE}$ might be estimable by eq 1 .

Photoionization ionization efficiency (PIE) curves for losses of $R^{\prime}$ and $R^{\prime} H$ (Figures 2-4) provide $\triangle A E$ and other information on competition between the two processes. Appearance energies derived from such measurements are given in Table 1 . The number of ions formed at an ion energy content corresponding to a value on the abscissa minus the ionization energy of the parent molecule is proportional to the slope of the corresponding PIE curve at that point [6]. That is, at energies at which a curve is rising steeply, the corresponding process is substantial, and at energies where the curve is horizontal, no product containing the full energy $h y-$ IE is formed. As with previously studied alkane eliminations $[1,3]$, all of the curves for alkane eliminations reach plateaus not too far above the onset of $R^{\prime}$ loss, confirming again that complex-mediated alkane eliminations are largely confined to a narrow energy range near threshold. The decompositions of metastable ions provide reaction patterns very close to threshold.

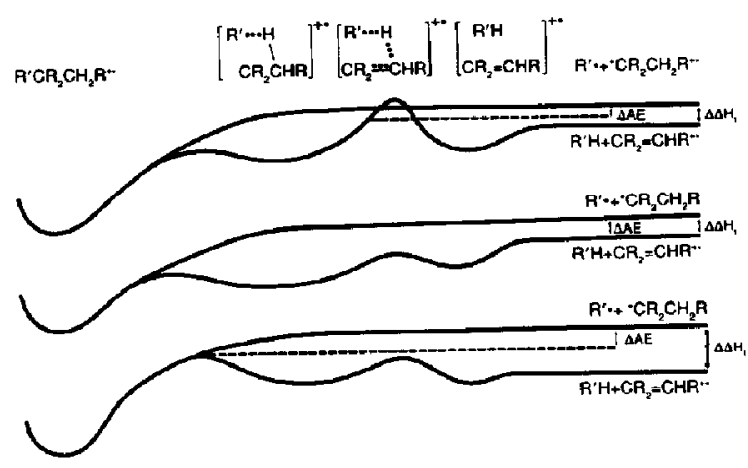

Figure 1. Sections through the potential energy surfaces for complex-mediated dissociations. The species present in each region of the curve is depicted above that section. $R^{\prime}$ represents an alkyl radical, and $\mathrm{R}$ may be $\mathrm{H}$, an alkyl radical, or some other moiety. The upper pair of traces represents a case in which the barrier to H-transfer is higher than the threshold for simple dissociation. In this case, the threshold for alkane elimination may be set by tunneling through this barrier [5]. In the middle pair of traces complex formation and H-transfer occur below the thermochemical threshold for alkane elimination, so $\Delta \mathrm{AE}$ and $\Delta \Delta H_{f}$ will be identical. In the bottom pair of traces the transition state for complex formation is above that for $\mathrm{H}$-transfer, so the threshold for alkane elimination is set by the threshold for $\left[\mathrm{R}^{\prime} \mathrm{CR}_{2} \mathrm{CH}_{2} \mathrm{R}\right]^{+\cdot}$ formation. In this case, $\triangle \mathrm{AE}$ will be substan- tially smaller than $\Delta \Delta \mathbf{H}_{f}$.

A problem in the data is that $\triangle \mathrm{AE}$ is sometimes larger than the differences between published (see Appendix) heats of formation $\left(\Delta \Delta \mathrm{H}_{\mathrm{f}}\right)$ for the products (Table 2), reflecting inconsistency between published and presently derived heats of formation of the vinyl ether products (see below). The following discussion will assume that the AE measurements reflect the threshold differences, as these measurements were made under the same conditions.

Product ion identity. To establish the validity of Scheme I, we confirmed the identity of the products of alkane elimination from the ionized ethers. Melhane elimination from ionized isopropyl methyl ether forms the methyl vinyl ether ion [3a,7]. The cotlisionally activated dissociation (CAD) spectrum of the product of ethane elimination from the metastable sec-butyl methyl ether ion matches closely that of ionized methyl vinyl ether (Iable 3) and differs significantly from published CAD spectra of other $\mathrm{C}_{3} \mathrm{H}_{6} \mathrm{O}^{+\cdot}$ ions [8]. Ethane eliminated from the ionized sec-butyl methyl ether ion is composed of the ethyl and a methyl $\mathrm{H}$ from the sec-butyl group [9]. These results are consistent with ethane elimination from ionized sec-butyl methyl ether forming $\mathrm{CH}_{3} \mathrm{OCH}=\mathrm{CH}_{2}^{+*}$, as depicted in Scheme I. Similarly, the CAD spectra of the products of metastable $\mathrm{RH}$ elimination from a series of ethyl sec-alkyl ethers match well the $\mathrm{CAD}$ spectrum of $\mathrm{CH}_{3} \mathrm{CH}_{2} \mathrm{OCH}=\mathrm{CH}_{2}^{+-}$(Table 3). The CAD spectra of most $\mathrm{C}_{4} \mathrm{H}_{8} \mathrm{O}^{+}$ions [10] contain large peaks at $m / z 57$, in contrast to the low abundance of 
Table 1. Photoionization appearance energies and derived thermochemistry for ionized ethers

\begin{tabular}{|c|c|c|c|c|c|c|c|}
\hline Ether & $\mathrm{IE}$ & $A E(-R)$ & $\mathrm{AE}(-\mathrm{RH})$ & $\Delta \mathrm{H}_{\mathrm{cor}}(-\mathrm{R})^{\mathrm{a}}$ & $\Delta \mathrm{H}_{\text {cor }}(-\mathrm{RH})^{\mathrm{a}}$ & $\Delta H_{f}(-R)^{b}$ & $\Delta \mathrm{H}_{\mathrm{f}}(-\mathrm{RH})^{\mathrm{b}}$ \\
\hline $\mathrm{CH}_{3} \mathrm{OC} H\left(\bar{C} \mathrm{H}_{3} \bar{l}_{2}\right.$ & 917 & 937 & 935 & 20 & 18 & 561 & 776 \\
\hline $\mathrm{CH}_{3} \mathrm{OCH}\left(\mathrm{CH}_{3}\right) \mathrm{C}_{2} \mathrm{H}_{5}$ & 898 & 927 & 901 & 22 & 20 & 559 & 733 \\
\hline $\mathrm{CH}_{3} \mathrm{OCH} / \mathrm{CH}_{3} / \mathrm{C}_{3} \mathrm{H}_{3}$ & $896^{\mathrm{C}}$ & 924 & $<896^{d}$ & 24 & 22 & 560 & $\leq 730$ \\
\hline $\mathrm{CH}_{3} \mathrm{OCH}\left(\mathrm{CH}_{3}\right) \mathrm{C}_{4} \mathrm{H}_{9}$ & 895 & 928 & $\leq 895^{d}$ & 26 & 24 & 567 & $\leq 731$ \\
\hline $\mathrm{CH}_{3} \mathrm{CH}_{2} \mathrm{OCH}\left(\mathrm{CH}_{3}\right)_{2}$ & 898 & 900 & $-{ }^{a}$ & 22 & 20 & 491 & - \\
\hline $\mathrm{CH}_{3} \mathrm{CH}_{2} \mathrm{OCH}\left(\mathrm{CH}_{3}\right) \mathrm{C}_{2} \mathrm{H}_{5}$ & 891 & 898 & 895 & 24 & 22 & 498 & 694 \\
\hline $\mathrm{CH}_{3} \mathrm{CH}_{2} \mathrm{OCH}\left(\mathrm{CH}_{3}\right) \mathrm{C}_{3} \mathrm{H}_{7}$ & 886 & 916 & 894 & 26 & 24 & 519 & 695 \\
\hline $\mathrm{CH}_{3} \mathrm{CH}_{2} \mathrm{OCH}\left(\mathrm{CH}_{3}\right) \mathrm{C}_{4} \mathrm{H}_{9}$ & 885 & 916 & 895 & 28 & 26 & 522 & 698 \\
\hline $\mathrm{CH}_{3} \mathrm{CH}_{2} \mathrm{CH}_{2} \mathrm{OCH}\left(\mathrm{CH}_{3}\right) \mathrm{C}_{2} \mathrm{H}_{6}$ & 887 & 900 & 893 & 26 & 24 & 480 & 672 \\
\hline$\left(\mathrm{CH}_{3}\right)_{2} \mathrm{CHOCH}\left(\mathrm{CH}_{3}\right) \mathrm{C}_{2} \mathrm{H}_{6}$ & 871 & 891 & 881 & 28 & 26 & 462 & 652 \\
\hline$\left[\mathrm{CH}_{3} \mathrm{CH}_{2} \mathrm{CH}\left(\mathrm{CH}_{3}\right)\right]_{2} \mathrm{O}$ & 870 & 880 & 875 & 30 & 8 & 432 & 627 \\
\hline
\end{tabular}

Alt values are $\mathrm{kJ} \mathrm{mol}^{-1}$.

Related published heats of formation are given in the Appendix.

${ }^{a} \Delta \mathrm{H}_{\mathrm{corr}}$ is a statistical mechanical correction factor for thermal energy content [15a]; most $\Delta \mathrm{H}_{\mathrm{cor}} \mathrm{values}$ were estimated basad on computed reference values and normal increments por added $\mathrm{CH}_{2}$ group.

${ }^{b}$ The procedure whereby heats of formation of product ions were obtained from the AE measurements is described under Experimental.

Measured onset uncertain.

dValues are upper limits because AE equals the ionization potential of the precursor compound.

Fon abundance too low to permit AE measurement.

that species in the $\mathrm{C}_{4} \mathrm{H}_{8} \mathrm{O}^{+\cdot}$ spectra obtained in the present study. Thus, the alkane eliminations we examine here appear to form vinyl ether ions, in accord with Scheme I.

Effect of the size of the ionic partner on alkane elimination. The size of the ion in the complex was increased by increasing the size of $R$ in isopropyl and sec-butyl ether ions. The importance of methane loss from metastable isopropyl ether ions decreases as the size of the ionic partner increases (I'able 4). 'I'he patterns vary from negligible methyl loss from ionized isopropyl methyl ether to negligible methane loss from ionized $n$-butyl isopropyl ether, a variation greater than $10^{4}$ in the ratio of the abundances of the two products. Methane elimination from metastable tertbutyl ether ions also diminishes rapidly in importance with increasing size of the ionic partner (Table 5). Thus, alkane eliminations from metastable ions can vary dramatically with the size of the ionic partner in the complex. However, metastable sec-butyl ether ions lose only ethane, presumably reflecting the effect of the larger neutral partner (see below).

Competition between $\mathrm{R}^{\prime} \mathrm{H}$ elimination and $\mathrm{R}^{\prime}$ loss above the threshold for the latter may also influence the $-\mathbf{R}^{\prime} \mathbf{H} /-\mathbf{R}^{\prime}$ ratio $[3 b]$. In general, as $R$ increased in size while $R^{\prime}$ was kept constant, the portion of the PIE curve for $R^{\prime} H$ elimination above that for $R^{\prime}$ loss decreased, demonstrating diminishing competition of the first process with the second (Figure 2). This
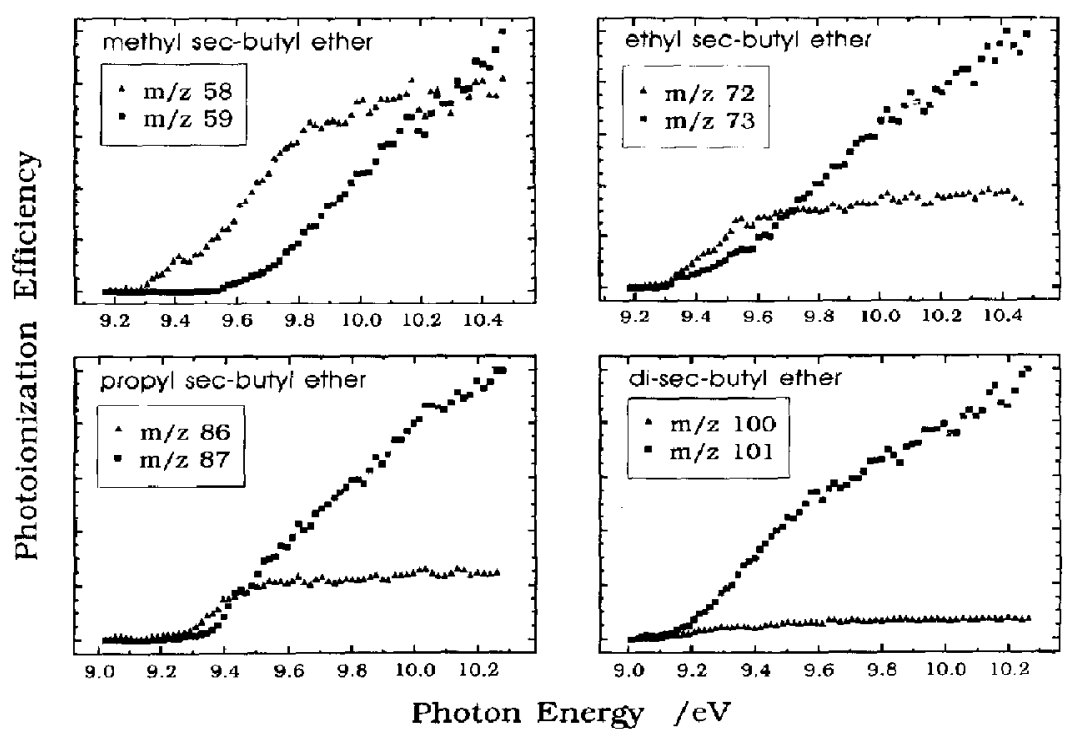

Figure 2. Photoionization ionization efficiency curves for the losses of $\mathrm{R}^{\prime}$ and $\mathrm{R}^{\prime} \mathrm{H}$ from $\mathrm{ROCH}\left(\mathrm{CH}_{3}\right) \mathrm{R}^{\prime+\cdot}$ ions. These curves demonstrate that as the size of $\mathrm{R}$ increases, the competitiveness of $\mathrm{R}^{\prime} \mathrm{H}$ elimination with loss of $\mathrm{R}^{\prime}$ decreases markedly. 


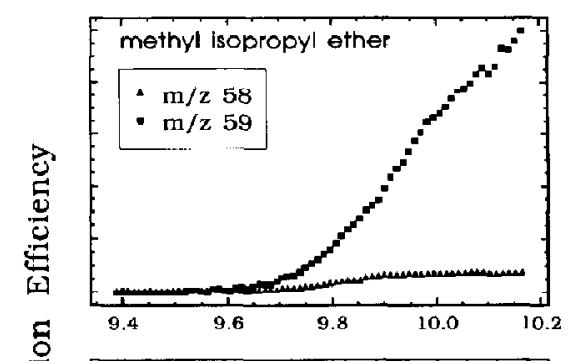

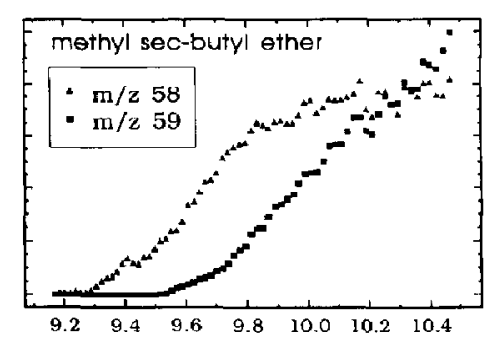

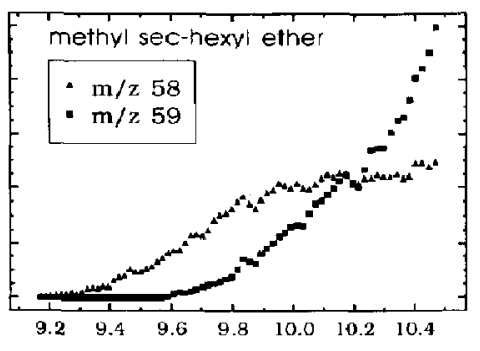

Figure 3. Photoionization ionization efficiency curves demonstrating the effect of increasing the size of $\mathbf{R}^{\prime}$ on the losses of $R^{\prime}$ and $R H$ from $\mathrm{CII}_{3} \mathrm{OCH}\left(\mathrm{CII}_{3}\right) \mathrm{R}^{\prime+}$ jons. These curves indicate that as the size of $\mathrm{R}^{\prime}$ increases from methyl to ethyl, the competitiveness of $\mathrm{RH}$ elimination with loss of $R^{\prime}$ increases markedly.

Photon Energy /eV

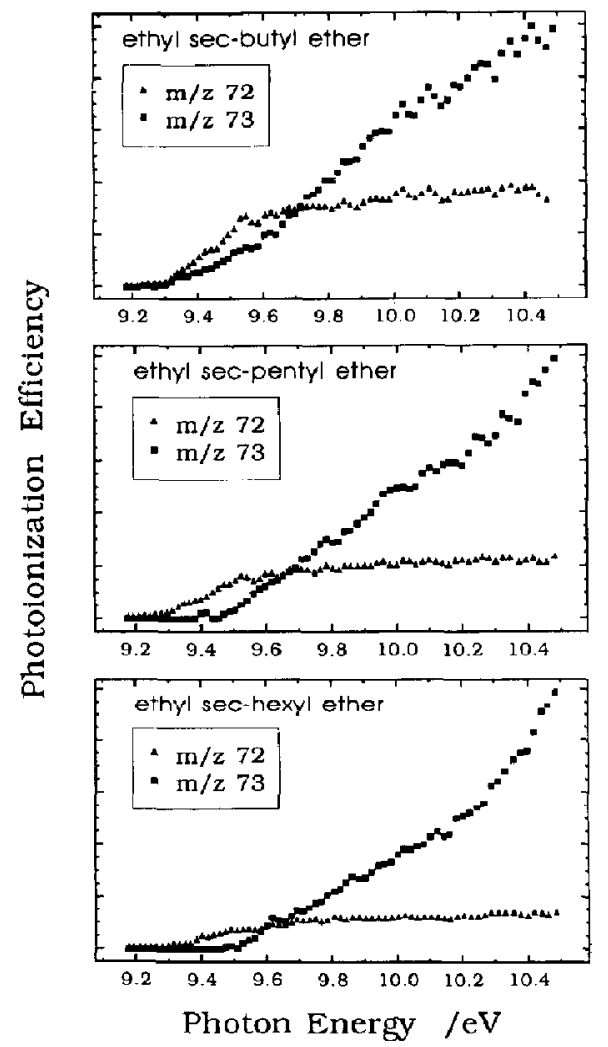

Figure 4. Photoionization ionization efficiency curves for the losses of $\mathrm{R}^{\prime}$ and $\mathrm{R}^{\prime} \mathrm{H}$ from $\mathrm{C}_{2} \mathrm{H}_{5} \mathrm{OCH}\left(\mathrm{CH}_{3}\right) \mathrm{R}^{\prime+}$ ions. In contrast to the methyl ethers, as the size of $R^{\prime}$ increases, the competitiveness of $\mathrm{R}^{\prime} \mathrm{H}$ elimination with loss of $\mathrm{R}^{\prime}$ seems to decrease. parallels previous observations on ionized ketones [1]. Competition above the threshold for simple dissociation was assessed in a qualitative way by subtracting $\mathrm{AE}\left(\mathrm{R}^{+} \mathrm{OCHCH}_{3}\right)$ from the energies at which the PIE curves for loss of $\mathrm{R}^{\prime}$ and $\mathrm{R}$ H elimination crossed, that is, the photon energies at which the formation of the two species are equal. These crossover energies decreased rapidly as $R$ increased in size (Table 4 ). Thus, increasing the size of the ion in the complex reduces the direct competitiveness of RH elimination with $R^{\prime}$ loss.

$\triangle \mathrm{AE}$ decreases dramatically on going from methyl to ethyl sec-butyl ether ions, but varies erratically between 5 and $10 \mathrm{~kJ} \mathrm{~mol}^{-1}$ in the larger sec-butyl ether ions. Branching in $R$ would weaken the $C-C$ bond cleaved, so the values from ions with such branching may not be comparable to the others.

As $\Delta \mathrm{H}_{\mathrm{f}}\left(\mathrm{CH}_{3} \mathrm{OCH}=\mathrm{CH}_{2}^{+}\right)$derived from the $\mathrm{AE}$ of

Table 2. Differences $A E\left(-R^{\prime}\right)-A E\left(-R^{\prime} H\right)$ and $\Delta H_{f}\left(-R^{\prime}\right)-\Delta H_{f}\left(-R^{\prime} H\right)$

\begin{tabular}{|c|c|c|c|c|}
\hline \multirow[b]{2}{*}{ Ether } & \multicolumn{2}{|c|}{$\mathrm{CH}_{3} \mathrm{OCH}\left(\mathrm{CH}_{3}\right) \mathrm{R}^{\prime}$} & \multicolumn{2}{|c|}{$\mathrm{C}_{2} \mathrm{H}_{5} \mathrm{OCH}\left(\mathrm{CH}_{3}\right) \mathrm{R}$} \\
\hline & $\triangle \mathrm{AE}^{\mathrm{a}}$ & $\Delta \Delta H_{f}^{b}$ & $\triangle \mathrm{AE}^{\mathrm{C}}$ & $\Delta \Delta H_{f}^{d}$ \\
\hline $\mathrm{ROCH}\left(\mathrm{CH}_{3}\right)_{2}$ & 2 & 26 & - & 32 \\
\hline $\mathrm{ROCH} / \mathrm{CH}_{3} / \mathrm{C}_{2} \mathrm{H}_{5}$ & 26 & 8 & 3 & 14 \\
\hline $\mathrm{ROCH}\left(\mathrm{CH}_{3}\right) \mathrm{C}_{3} \mathrm{H}_{7}$ & $\geq 28^{\mathrm{e}}$ & 7 & 22 & 13 \\
\hline $\mathrm{ROCH}\left\langle\mathrm{CH}_{3}\right) \mathrm{C}_{4} \mathrm{H}_{9}$ & $\geq 33^{\mathrm{e}}$ & 6 & 21 & 12 \\
\hline
\end{tabular}

All values are $\mathrm{kJ}^{\mathrm{mol}} \mathrm{l}^{-1}$.

${ }^{a} \mathrm{AE}\left(\mathrm{CH}_{3}^{+} \mathrm{OCHCH} \mathrm{H}_{3}\right)-\mathrm{AE}\left(\mathrm{CH}_{3} \mathrm{OCH}=\mathrm{CH}_{2}^{+}\right)$.

${ }^{\circ} \Delta \mathrm{H}_{\mathrm{f}}\left(\mathrm{CH}_{3}^{+} \mathrm{OCHCH}_{3}\right)+\Delta \mathrm{H}_{\mathrm{f}}\left(\mathrm{R}^{\prime}\right]-\left[\Delta \mathrm{H}_{1}\left(\mathrm{CH}_{3} \mathrm{OCH}=\mathrm{CH}_{2}^{+}\right)+\right.$ $\Delta H_{f}\left(R^{\prime}(H)\right]$ from published values.

${ }_{\mathrm{AE}}\left(\mathrm{CH}_{3} \mathrm{CH}_{2}^{+} \mathrm{OCHCH}_{3}\right)-\mathrm{AE}\left(\mathrm{CH}_{3} \mathrm{CH}_{2} \mathrm{OCH}=\mathrm{CH}_{2}^{+}\right)$.

${ }^{d} \mathrm{H}_{f}\left(\mathrm{CH}_{3} \mathrm{CH}_{2}^{+} \mathrm{OCHCH}\right)+\Delta \mathrm{H}_{4}\left(\mathrm{~A}^{\prime}\right)-\left[\Delta \mathrm{H}_{1}\left(\mathrm{CH}_{3} \mathrm{CH}_{2} \mathrm{OCH}=\right.\right.$ $\left.\left.\mathrm{CH}_{2}^{+}\right)+\Delta \mathrm{H}_{f}\left(\mathrm{R}^{\prime} \mathrm{H}\right)\right)$.

- Values are given as $\geq$ because the lower AE values are maximum values (Table 1 ). The individual heats of formation from which the $\Delta \Delta \mathrm{H}_{\mathrm{f}}$ values are derived are given in the Appendix. 


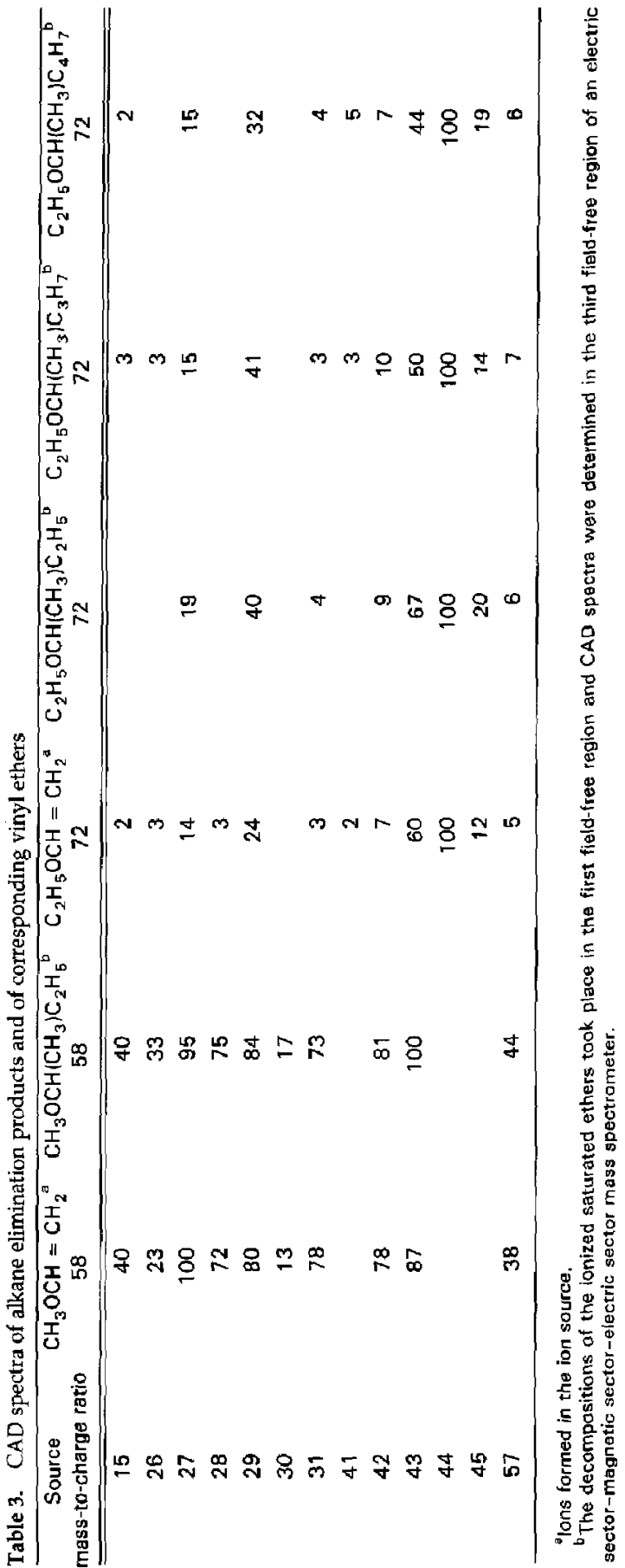


Table 4. Effect of size of $\mathrm{R}$ on $\mathrm{R} H$ elimination from $\mathrm{ROCH}\left(\mathrm{CH}_{3}\right) \mathrm{R}^{\prime}$ ethers

\begin{tabular}{|c|c|c|c|c|}
\hline \multirow[b]{2}{*}{$\mathbf{R}$} & \multirow{2}{*}{$\begin{array}{c}\mathrm{ROCH}\left(\mathrm{CH}_{3}\right) \mathrm{CH}_{3} \\
-\mathrm{CH}_{3} /-\mathrm{CH}_{4}{ }^{\mathrm{a}}\end{array}$} & \multicolumn{3}{|c|}{$\mathrm{ROCH}\left(\mathrm{CH}_{3}\right) \mathrm{C}_{2} \mathrm{H}_{5}$} \\
\hline & & $-\mathrm{C}_{2} \mathrm{H}_{5} /-\mathrm{C}_{2} \mathrm{H}_{6}^{\mathrm{a}}$ & $\Delta \mathrm{AE}$ & Crossover $^{\text {b }}$ \\
\hline$\overline{\mathrm{CH}_{3}}$ & $<0.01$ & $<0.01$ & 26 & 69 \\
\hline $\mathrm{C}_{2} \mathrm{H}_{5}$ & 1.9 & 0.02 & 3 & 38 \\
\hline $\mathrm{CH}_{3} \mathrm{CH}_{2} \mathrm{CH}_{2}$ & 100 & c & 7 & 14 \\
\hline$\left(\mathrm{CH}_{3}\right)_{2} \mathrm{CH}$ & c & $<0.01$ & 10 & $\mathbf{3}$ \\
\hline $\mathrm{CH}_{3} \mathrm{CH}_{2} \mathrm{CH}_{2} \mathrm{CH}_{2}$ & $>500$ & $\mathbf{c}$ & $\mathbf{c}$ & c \\
\hline $\mathrm{CH}_{3} \mathrm{CH}_{2} \mathrm{CH}\left(\mathrm{CH}_{3}\right)$ & $>100$ & $<0.02$ & 5 & -0 \\
\hline
\end{tabular}

$\triangle A E$ and crossover values are $\mathrm{kJ}^{\mathrm{mol}}{ }^{-1}$.

${ }^{a}$ Ratios of the heights of peaks representing metastable decompositions.

bhoton energy at which the two fragmentations are equal minus $\mathrm{AE}\left(\mathrm{RO}{ }^{+} \mathrm{CHCH}_{3}\right)$ (see text).

cData not obtained.

that ion formed from sec-butyl methyl ether was as low as any obtained, this ion is probably formed close to its thermochemical threshold, that is, the onsets of complex formation and $\mathrm{H}$-transfer between the partners are below the combined heats of formation of the - R'H products. In this situation, the middle traces of Figure 1 represent the potential surface for decomposition. The decrease in $\triangle \mathrm{AE}$ on going from $\mathrm{R}=\mathrm{CH}_{3}$ to larger alkyl groups suggests that as the ionic partner increases in size, the threshold becomes determined by the onset of bond dissociation rather than product stability. This is the behavior depicted by the bottom traces in Figure 1.

Alkane eliminations were too weak to permit measuring appearance energies for loss of methane from ionized isopropyl ethers larger than the methyl or any of the ionized tert-butyl ethers, further evidence that increasing the size of the ion in the complex decreases alkane elimination.

There has been disagreement about whether there is a metastable loss of methyl from ionized isopropyl methyl ether $[3 a, 7]$. The resolution of the conflicting reports is that metastable methyl loss from the unlabeled ion is undetectable (present experiments, ref 7), but there is metastable loss of $\mathrm{CH}_{3}$ when one $\mathrm{CD}_{3}$ is placed in the $i$-propyl group, as reported in ref $3 \mathrm{a}$.

We attribute the generally decreased competitiveness of $\mathrm{R}^{\prime} \mathrm{H}$ elimination with $\mathrm{R}^{\prime}$ loss with increasing size of $R$ to the effect of increasing $r$ predicted by eq 1 .

Effect of the size of the neutral partner on alkane elimination. The dependence of RH elimination on the size of the neutral radical in the intermediate complex was examined by varying $R^{\prime}$ from $\mathrm{CH}_{3}$ to $n-\mathrm{C}_{4} \mathrm{H}_{9}$ in

Table 5. Metastable decompositions of ionized tert-butyl ethers

\begin{tabular}{lc}
\hline Ether & $-\mathrm{CH}_{3} /-\mathrm{CH}_{4}$ \\
\hline \hline $\mathrm{CH}_{3}-0$-tert-Bu & 0.75 \\
$\mathrm{C}_{2} \mathrm{H}_{5}-0$-tert-Bu & 50 \\
$\mathrm{C}_{3} \mathrm{H}_{7}-0$-tert-Bu & $>300$
\end{tabular}

$\mathrm{CH}_{3}$ and $\mathrm{CH}_{4}$ come from the tert-butyl groups funpublished observations on deuterated tert-butyl ether ions).

$-\mathrm{CH}_{4}$ abundances were too low to permit AE measurements. methyl and ethyl ether ions. The loss of $\mathrm{R}^{\prime} \mathrm{H}$ from metastable ethyl ether ions becomes more important relative to loss of $R^{\prime}$ as the size of $R^{\prime}$ increases from $\mathrm{CH}_{3}$ to $\mathrm{C}_{3} \mathrm{H}_{7}$ (Table 6). The methyl ether ions lose $R^{\prime} H$ to the exclusion of $R^{\prime}$ in metastable decompositions, preventing comparison of $-\mathrm{R}^{\prime}$ and $-\mathrm{R}^{\prime} \mathrm{H}$ abundances in that series. The dominance of these alkane losses is attributable to the smaller size of the ionic partner.

$\triangle \mathrm{AE}$ for the methyl ethers increases as $\mathrm{R}^{\prime}$ became larger, with a large jump between the ${ }^{\circ} \mathrm{CH}_{3}$ and $\mathrm{C}_{2} \mathrm{H}_{5}$ partners (Table 2). The products of methane elimination are $26 \mathrm{~kJ} \mathrm{~mol}^{-7}$ more stable than those of methyl loss from ionized isopropyl methyl ether, whereas the corresponding $\Delta \mathrm{AE}=2 \mathrm{~kJ} \mathrm{~mol}^{-1}$. These results indicate a significant reverse activation energy for this methane elimination. This is confurmed by translational energy releases, ca. $4 \mathrm{~kJ} \mathrm{~mol}^{-1}$ for ionized isopropyl methyl ether versus ca. $1 \mathrm{~kJ} \mathrm{~mol}^{-1}$ for sec-butyl methyl ether. (Energy releases were derived from the widths at half maximum height of peaks representing metastable decompositions using the formula $\mathrm{T}_{0.5}=\mathrm{V}(\Delta \mathrm{m})^{2} / 16 \mathrm{~m}_{2} \mathrm{~m}_{3}$ [11].) The PIE curves (Figure 3) demonstrate that methane loss from ionized isopropyl methyl ether is the least competitive alkane elimination in the methyl ether series, despite its being the most thermochemically favored. We suggest the threshold-determining barrier in this reaction is the one to movement of methyl to the configuration for $\mathrm{H}$-transfer, the situation represented by the bottom traces in Figure 1. The presence of substantial secondary isotope effects [3a] supports a relatively

Table 6. Effect of size of $R^{\prime}$ on $R$ ' $H$ elimination from $\mathrm{ROCH}\left(\mathrm{CH}_{3}\right) \mathrm{R}^{+*}$ ions

\begin{tabular}{lccccc}
\hline & \multicolumn{2}{c}{$\mathrm{CH}_{3} \mathrm{OCH}\left(\mathrm{CH}_{3}\right) \mathrm{R}^{\prime}$} & & \multicolumn{2}{c}{$\mathrm{C}_{2} \mathrm{H}_{5} \mathrm{OCH}\left(\mathrm{CH}_{3}\right) \mathrm{R}^{\prime}$} \\
\cline { 2 - 3 } \cline { 6 - 6 } $\mathbf{R}^{\prime}$ & $-\mathrm{R}^{\prime} /-\mathrm{R}^{\prime} \mathrm{H}^{\mathrm{a}}$ & Crossover & & $-\mathrm{R}^{\prime} /-\mathrm{R}^{\prime} \mathrm{H}^{\mathrm{a}}$ & Crossover \\
\hline \hline $\mathrm{CH}_{3}$ & $<0.01$ & 0 & & 1.9 & - \\
$\mathrm{C}_{2} \mathrm{H}_{5}$ & $<0.01$ & 69 & & 0.02 & 38 \\
$\mathrm{C}_{3} \mathrm{H}_{7}$ & $<0.5$ & 62 & & $<0.01$ & 18 \\
$\mathrm{C}_{4} \mathrm{H}_{9}$ & $<0.05$ & 55 & & $<0.01$ & 11 \\
\hline
\end{tabular}

Crossover values are $\mathrm{ks} \mathrm{mol}^{-1}$.

"Ratios of the heights of peaks representing metastable decompositions. 
high energy for the transition state for bond cleavage relative to that for subsequent $\mathrm{H}$-transfer. Because methyl is very weakly bound, the threshold for methane elimination is close to the energy needed for simple dissociation and substantially above the combined heats of formation of the products of methane elimination. A portion of this excess energy becomes translational energy during decomposition.

For higher members of the methyl ether series, $\Delta \mathrm{AE}=26-33 \mathrm{~kJ} \mathrm{~mol}^{-1}$, even though $\Delta \Delta \mathrm{H}_{\mathrm{f}}$ is only about $6-8 \mathrm{~kJ} \mathrm{~mol}^{-1}$ (Table 2). This reflects a discrepancy between published heats of formation of the vinyl ether ions and the $\Delta \mathrm{H}_{f} \mathrm{~s}$ derived from our $\mathrm{AE}\left(\mathrm{CH}_{3} \mathrm{OCH}=\mathrm{CH}_{2}^{+}\right.$) values (see below). $\Delta \mathrm{H}_{\mathrm{f}}\left(\mathrm{CH}_{3}^{+} \mathrm{OCHCH}_{3}\right)$ values derived from the measured $\mathrm{AE}$ values are fairly constant and agree well with previous values $[3 \mathrm{a}, 12]$, so the increasing $\triangle \mathrm{AE}$ values are due to decreasing $\mathrm{AE}\left(\mathrm{CH}_{3} \mathrm{OCH}=\mathrm{CH}_{2}^{+}\right)$ values relative to expected ones. $\triangle \mathrm{AE}$ does not continue to become larger for the larger methyl ethers because the appearance energies of the alkane eliminations become equal to the ionization energies of the ethers, the lower limit for an AE. This could prevent $\triangle \mathrm{AE}$ for the losses of $\mathrm{C}_{3} \mathrm{H}_{8}$ and $\mathrm{D}_{4} \mathrm{H}_{10}$ from reflecting the threshold for hydrogen transfer. However, the AEs in question are probably not much too low, as they give the lowest values for $\Delta \mathrm{H}_{\mathrm{f}}\left(\mathrm{CH}_{3} \mathrm{OCH}=\right.$ $\mathrm{CH}_{2}^{+}$), which, as already noted, seem too low. The observation of molecular ions also implies that the measured AEs are not much too low. The larger forces of attraction with increasing size and therefore polarizability of $R^{\prime}$ (Table 7 ) should stabilize ( $\left.\left[\mathrm{RO}^{+} \mathrm{CHCH}_{3} \mathrm{R}^{\prime}\right]\right)$ relative to $\mathrm{ROCH}=\mathrm{CH}_{2}^{+}+\mathrm{R}^{\prime} \mathrm{H}$. Therefore, $\Delta \mathrm{AE}$ could become equal to $\Delta \Delta \mathrm{H}_{\mathrm{f}}$ with increasing size of $R^{\prime}$ in the methyl ether ions, the situation depicted by the middle traces in Figure 1. The low $A E\left(-R^{\prime} H\right)$ values suggest that this condition is reached in the eliminations of the larger alkanes from ionized sec-alkyl methyl ethers.

The crossover energies are fairly constant from 2-butyl to 2-hexyl methyl ether. This suggests that increasing the size of $R^{\prime}$ does not make - RH more competitive than $-R^{\prime}$ above the threshold for the latter process.

Ion-induced dipole attractions should increase substantially with each increment in size of the radical in the complex duc to corrcsponding increases in the polarizability of alkyl radicals. This accounts for the

Table 7. Polarizabilities

\begin{tabular}{clll}
\hline $\mathrm{C} \mathrm{H}_{4}$ & 2.60 & & \\
$\mathrm{C}_{2} \mathrm{H}_{6}$ & 4.44 & $\mathrm{C}_{3} \mathrm{H}_{5}$ & 2.7 \\
$\mathrm{C}_{3} \mathrm{H}_{8}$ & 6.29 & $n-\mathrm{C}_{3} \mathrm{H}_{7}$ & 4.54 \\
$n-\mathrm{C}_{4} \mathrm{H}_{10}$ & 8.14 & $n-\mathrm{C}_{4} \mathrm{H}_{9}$ & 6.39 \\
\hline
\end{tabular}

Values are in $\AA^{3}$. Values for the alkanes are from ref 16 ; the value for the methyl radical is from Klots $\mid 171$, and the values for the remaining radicals are estimated by adding the differences between the corresponding alkane values and the value for methane to the value for methyl. large increase in $\triangle \mathrm{AE}$ on going from $\mathrm{R}^{\prime}=\mathrm{CH}_{3}$ to $\mathbf{R}^{\prime}=\mathrm{C}_{2} \mathrm{H}_{5}$ in the ionized methyl ethers. This change in $\triangle \mathrm{AE}$ is large because it occurs in the window between $\Delta \mathrm{H}_{\mathrm{f}}\left(\mathrm{CH}_{3} \mathrm{O}^{+} \mathrm{CHCH}_{3}\right)+\Delta \mathrm{H}_{\mathrm{f}}\left(\mathrm{R}^{\prime}\right)$ and $\Delta \mathrm{H}_{\mathrm{f}}\left(\mathrm{CH}_{3} \mathrm{OCH}=\mathrm{CH}_{2}^{++}\right)+\Delta \mathrm{H}_{\mathrm{f}}\left(\mathrm{R}^{\prime} \mathrm{H}\right)$. The $24 \mathrm{~kJ} \mathrm{~mol}^{-1}$ change in $\triangle \mathrm{AE}$ between $\mathrm{R}^{\prime}=\mathrm{CH}_{3}$ and $\mathrm{R}^{\prime}=\mathrm{C}_{2} \mathrm{H}_{5}$ provides an estimate of the change in the energy needed to form a $\left[\mathrm{CH}_{3}^{+} \mathrm{OCHCH}_{3}{ }^{{ }^{\prime}} \mathrm{R}^{\prime}\right]$ complex per methylene added in $R^{\prime}$, although tunneling [5] may blur this estimate.

$\triangle \mathrm{AE}$ for the alkane eliminations from the ionized ethyl ethers increases substantially as $R^{\prime}$ goes from ethyl to propyl but not from propyl to butyl. In contrast to observations on the methyl ether ions, $\mathrm{AE}\left(\mathrm{C}_{2} \mathrm{H}_{5} \mathrm{OCH}=\mathrm{CH}_{2}^{+}\right)$remains close to its thermochemical threshold, and $\mathrm{AE}\left(\mathrm{C}_{2} \mathrm{H}_{5}^{+} \mathrm{OCHCH}_{3}\right)$ rises with increasing size of $\mathrm{R}^{\prime}$ in the ionized ethyl ethers. Because $\mathrm{AE}\left(\mathrm{CH}_{3} \mathrm{CH}_{2} \mathrm{OCH}=\mathrm{CH}_{2}^{+}\right)$formed from ionized sec-butyl ethyl ether is at its thermochemical threshold, $\mathrm{AE}\left(\mathrm{ROCH}=\mathrm{CH}_{2}^{+}\right)$cannot decrease relative to its predicted value with increasing size of $\mathbf{R}^{\prime}$. The rise in $\mathrm{AE}\left(\mathrm{CH}_{3} \mathrm{CH}_{2}^{+} \mathrm{OCHCH}_{3}\right)$ relative to its thermochemical threshold with increasing size of $R^{\prime}$ could be attributed to increasing competition from $R^{\prime} H$ elimination near threshold. However, in contrast to the changes in $\triangle \mathrm{AE}$, the crossover energies decrease steadily as the size of $R^{\prime}$ increases in the ethyl ether ions (Table 6). This decrease occurs despite the upward shifts in the $A E\left(-R^{\prime}\right)$ values. The small areas between the PIE curves (Figure 4) also do not seem to indicate increasing RH elimination from the ethyl ethers as $\mathbf{R}^{\prime}$ increases in size from propyl to butyl. We do not have a clear explanation for this behavior.

$\Delta H_{f}$ of ionized methyl vinyl ether. $\Delta \mathrm{H}_{\mathbf{f}}\left(\mathrm{C}_{3} \mathrm{H}_{6} \mathrm{O}^{+}\right)$obtained from $\mathrm{AE}$ values from the larger methyl ethers are in the range $730-733 \mathrm{~kJ} \mathrm{~mol}^{-1}$ (Table 1), whereas $\Delta \mathrm{H}_{\mathrm{f2} 298}\left(\mathrm{CH}_{3} \mathrm{OCH}=\mathrm{CH}_{2}^{+-}\right)=754 \mathrm{~kJ} \mathrm{~mol}^{-1}$ [3a]. This discrepancy indicates errors in the published heats of formation, our measured thresholds, or in the assumed identity of the products. Good agreement between the $\Delta \mathrm{H}_{\mathrm{f}}$ values for $\mathrm{CH}_{3}^{+} \mathrm{OCHCH}_{3}$ in Table 1 and the published value suggest that most of the reference heats of formation are accurate. $A b$ initio calculations (Gaussian 86, HF/6-31G, ZPVE/3-21G [13]) compared $w$ ith the experimental $\Delta \mathrm{H}_{1}\left(\mathrm{CH}_{3} \mathrm{COCH}_{3}^{+}\right)$give $\Delta \mathrm{H}_{\mathrm{fLyy}}\left(\mathrm{CH}_{3} \mathrm{OCH}-\mathrm{CH}_{2}^{+*}\right)-$ $755.6 \mathrm{~kJ} \mathrm{~mol}^{-1}$. The agreement between theoretical and the published value suggests that the latter is not too high. Its heat of formation $\left(719 \mathrm{~kJ} \mathrm{~mol}^{-1}\right)$ [12] makes the acetone ion a candidate product of alkane elimination. However, its formation is inconsistent with the CAD spectra and is hard to rationalize on mechanistic grounds. It is also highly unlikely that a more stable product would be formed at threshold in the ion source than upon metastable decomposition. $\Delta \mathrm{H}_{1}\left(\mathrm{CH}_{3} \mathrm{CH}_{2} \mathrm{OCH}=\mathrm{CH}_{2}^{+}\right)$from the literature is also higher $\left(10-14 \mathrm{~kJ} \mathrm{~mol}^{-1}\right)$ than the values derived from our measurements (Table 1). 


\section{Summary}

Present studies demonstrate that as the size of the ionic partner in an ion-neutral complex increases, $\mathrm{H}$-transfers become less competitive with simple dissociation. This is attributed to decreasing attraction between the partners with increasing distance between the neutral and the center of charge in the ion as the ion incrcascs in sizc. However, as alkyl radicals in complexes become larger, the onsets for alkane eliminations are lowered relative to those for simple dissociation when product heats of formation permit. This is attributed to a decreasing threshold for alkane elimination relative to that for simple dissociation with increasing pularizability of and therefore stronger attraction to the radical.

\section{Experimental}

Decompositions were sampled between the magnetic sector and the second electric sector of a mass spectrometer of the geometry electric sector-magnetic sector-electric sector [14]. All metastable decompositions were determined at an electron impact energy of 70 $\mathrm{eV}$ and an ion source temperature of $200^{\circ} \mathrm{C}$. Collisionally activated dissociation spectra were determined by admitting helium to a collision cell to a pressure that gave $20 \%$ reduction in the abundance of the primary ion. To obtain CAD spectra of the products of metastable decompositions, the accelerating voltage and magnetic field were adjusted such that the products of first field-free region decompositions passed through the collision cell. Photoionization ionization efficiency curves were determined with a microprocessor-controlled photoionization mass spectrometer as described elsewhere [15]. AE values were obtained by linear extrapolation of the initial rising portion of the curve to the abscissa. Corrections for influences of thermal energy on the curves were made by comparisons to the PIE curves for the corresponding molecular ions. The AE measurements are reproducible to $\pm 1 \mathrm{~kJ} \mathrm{~mol}^{-1}$, but the uncertainties due to the contribution of thermal energy can be larger. Heats of formation for fragment ions formed by the process

$$
\mathrm{AB}+\mathrm{h} \boldsymbol{p} \rightarrow \mathrm{A}^{+}+\mathrm{B}
$$

are related to their AEs by the following formula (assuming no reverse activation energy barriers are present):

$$
\begin{aligned}
\Delta \mathrm{H}_{\mathrm{f} 298}\left(\mathrm{~A}^{+}\right)= & A E\left(\mathrm{~A}^{+}\right)-\Delta \mathrm{H}_{\mathrm{f}}(\mathrm{B}) \\
& +\Delta \mathrm{H}_{\mathrm{f}}(\mathrm{AB})+\Delta \mathrm{H}_{\mathrm{cor}}
\end{aligned}
$$

where $\Delta \mathrm{H}_{\text {cor }}$ is a statistical mechanical correction for thermal energy content that adjusts $\Delta \mathrm{H}_{\mathrm{f}}\left(\mathrm{A}^{+}\right)$to $298 \mathrm{~K}$ [15a]. ods.

\section{Acknowledgments}

We thank the Robert A. Welch Foundation (H-609 to DJM and A1106 to LLG), the Petroleum Research Fund, and the Australian Research Grants Scheme for financial support, Ms. Barbara Kompe for the ab initio calculation of $\Delta \mathrm{H}_{f}\left(\mathrm{CH}_{3} \mathrm{OCH}=\right.$ $\mathrm{CH}_{2}^{+}$), Professor Michael Gross and the NSF-supported Midwest Center for Mass Spectrometry for use of the Kratos MS 50TA mass spectrometer, and Ms. Debbie Pavlu for typing.

\section{References}

I. Traeger, J. C.; Hudson, C. E.; McAdoo, D. J. J. Phys. Chem. 1988, 92, 1519.

2. (a) Wendelboe, J. F.; Bowen, R. D.; Williams, D. H. J. Am. Chem. Soc. 1981, 103, 2333. (b) Tumas, W.; Foster, R. F.; Pellerite, M. J.; Brauman, J. I. J. Am. Chem. Soc. 1983, 105, 7464. (c) Hudson, C. E.; McAdoo, D. J. Int. J. Mass Spectrom. Ion Proc. 1984, 59, 325. (d) Hammerum, S. J. Chem. Soc. Chem. Commun. 1988, 858, (e) Bowen, R. D.; Maccoll, A. J. Chem. Soc. Perkin Trans. 1990, 2, 147.

3. (a) McAdoo, D. I.; Traeger, J. C.; Hudson, C.E.; Griffin, L. L. J. Phys, Chem, 1988, 92, 1524. (b) Traeger, J. C.; Hudson, C. E.; McAdoo, D. J. J. Phys. Chem. 1990, 94, 5714.

4. (a) Bowers, M. T.; Jarrold, M. F.; Wagner-Redeker, W.; Kemper, P. R.; Bass, L. M. Farad. Disc. Chem. Soc. 1983, 75, 57. (b) Redman, E. W.; Morton, T. H. J. Am. Chem. Soc. 1986, 108, 5701. (c) McAdoo, D. J. Mass Spectrom. Reo. 1988, $7,363$.

5. Heinrich, N.; Louage, F.; Lifshitz, C.; Sichwarz, H. J. Am. Chem. Soc. 1988, 110, 8183.

6. Hurzeler, H.; Inghram, M. G.; Morrison, J. D. I. Chem. Phys. 1958, 28, 76.

7. Weiske, T,; Akkok, S.; Schwarz, H. Int. J. Mass Spectram. Ion Proc. 1987, 76, 117.

8. Van de Sande, C. C.; McLafferty, F. W. J. Am. Chem. Soc. 1975, 97, 4617.

9. Hudson, C. E.; Lerner, R. D.; Aleman, R.; McAdoo, D. J. J. Phys. Chem. 1980, 84, 155.

10. McAdoo, D. J.; Hudson, C. E. Org. Muss Spectrom. 1983, 18, 466.

11. Cooks, R. G.; Beynon, J. H.; Caprioli, R. M.; Lester, G. R. Metastable Ions; Elsevier: Amsterdam, 1973; p 60.

12. Lias, S. G.; Bartmess, J. E.; Liebman, J. F.; Holmes, J. L.; Levin, R. D.; Mallard, W. J. I. Phys. Chem. Ref. Data 1988, 17. Suppl. 1.

13. Frisch, M. J.; Binkley, J. S.; Schlegel, H. B.; Raghavachari, K.; Melius, C. F.; Martin, R. L.; Stewart, J. J. P.; Bobrowicz, F. W.; Rohlfing, C. M.; Kahn, L. R.; DeFrees, D. J.; Seeger, R. A.; Whiteside, R. A.; Fox, D. J.; Fleuder, E. M.; Pople, J, A. Gaussian 86; Carnegie-Mellon Quantum Chemistry Publishing Unit, Pittsburgh, PA, 1984.

14. Gross, M. L.; Chess, E. K.; Lyon, P. A.; Crow, F. W.; Evans, S.; Tudge, H. Int. J. Mass Spectrom. Ion Phys. 1982, 42,243 .

15. (a) Traeger, J. C.; McLoughlin, R. G. J. Am. Chem. Soc, 1981, 103, 364\%. (b) Traeger, J. C.; McLoughlin, R. G; Nicholson, A. J. C. J. Am. Chem. Soc. 1982, 104, 5318. (c) Traeger, J. C. Org. Mass Spectrom. 1985, 20, 223.

16. Miller, K. J.; Saychik, J. A. J. Am. Chem. Soc. 1979, 101, 7206.

17. Klots, C. E. J. Chem. Phys. 1976, 64, 4269.

18. Pedley, J. B.; Rylance, J.; Susex-N. P. L. Computer Analyzed Thermochemical Data: Organic and Organometallic Compounds; University of Sussex, England, 1977.

19. (a) Castelhano, A. L.; Griller, D. J. Am. Chem. Soc. 1982, 104, 3655. (b) Seetula, J. A.; Russell, J. J.; Gutman, D. J. Am. Chem. Soc. 1990, 112, 1347. 
Appendix. Pertinent heats of formation

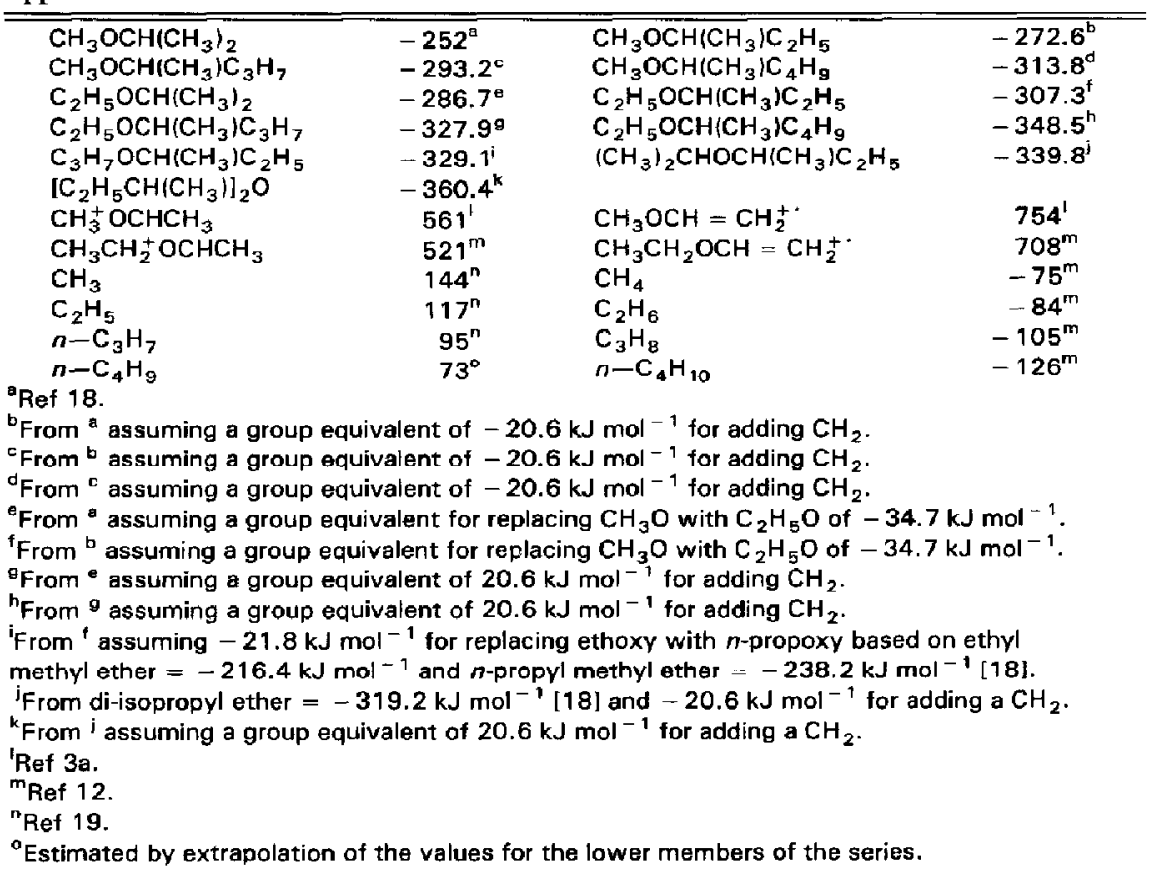

